\title{
Device Capable of Detecting Cavities and Objects for People with Visual Impairment
}

Ayax Israel Isidro Alvarado

Master in Information Technology, Villahermosa Technology Institute, Tabasco, México

Email: ayax94better@gmail.com

Victor Manuel Arias Peregrino

Postgraduate area in Information Technology, Villahermosa Technology Institute, Tabasco, México

Email: varper@itvillahermosa.edu.mx

Dulce María León de la 0

Postgraduate area in Information Technology, Villahermosa Technology Institute, Tabasco, México

Email: dulceleon_leon@hotmail.com

Alejandro Hernández Cadena

Postgraduate area in Information Technology, Villahermosa Technology Institute, Tabasco, México Email: alejandrohc1984@gmail.com

Jose Ángel Jesus Magaña

Postgraduate area in Information Technology, Villahermosa Technology Institute, Tabasco, México Email: joseangeljm@hotmail.com

\section{ABSTRACT}

Visual disability is a condition that affects $\mathbf{2 8 5}$ million people around the world, this sector of the society has a lot of tools for displacement, since a simple white cane that is the first thing that comes to our mind talking about visual disability to some technologic devices that assists them, nevertheless, these devices attack different difficulties, such as the detection of objects in front or the reading of signs in the public thoroughfare. However, there is a difficulty that has not been addressed; the detection of cavities or subsidence in the ground, this section must be taken into account as it can cause very serious accidents and for this reason a device designed to overcome this need is designed.

Keywords -Peripherals, Power Consumption, Visual disability/impairment, Sensor, White cane.

\section{INTRODUCTION}

$\mathrm{V}_{\mathrm{i}}$

isual impairment is a condition where vision is lost or it is very weak, and cannot be corrected with conventional or contact lenses. [1]

Around world there are approximately 285 million people with visual disabilities, of which 39 million are blind and 246 million have low vision. Visual impairment affects older people and women more. Approximately $85 \%$ of global cases of visual impairment are preventable. [2]

These people are able to move thanks to a very economical tool that allows them to increase their sensory perception, this tool is the white cane. This allows them to detect the presence of an object even before their bodies make contact, allowing them to move more safely and efficiently. In addition to being a scroll tool, it is a tool that identifies the other person as a person with visual impairment. However, despite this, in many cases the use of a mechanical system such as the white cane is not enough. [3]

In the field of technological applications developed for people with visual disabilities there are many projects that use the white cane [5], belts, lenses [6] and even vests to which sensors are implemented whose function is only to detect objects that are obstructing the path over the surface [7], some others are designed to also detect objects that are above the waist, preventing people with visual disabilities from hitting their heads.

While these projects are useful, they maintain various problems over time such as the autonomy of the device, the cost of production, overly striking designs, or lack of functionality.

\section{Methodology}

There are many ways in which a person with visual impairment can be supported, from the aforementioned white cane, through guide dogs or even with some technological device. There are several devices on the market, capable of helping people with visual disabilities. And there are many with different characteristics. From those who detect objects in front of the user, to those who use cameras to identify bills or read posters.

However, the device presented in this article is not only capable of detecting objects; It also offers a warning when the ground presents an irregularity, such as a step or an uncovered strainer. We sought to make a design that was economical but as functional as possible, in order to reduce costs while offering assistance. 


\subsection{Components}

As for components that can be used in a project, they are diverse and of various characteristics, however, the following were used for their ease of use, reliability and price.

\section{Microcontrollerr:}

The brain of this project is an Arduino mini, this is a very popular microcontroller that is commonly used in the creation of various projects due to its low cost and ease of use; It has a very small size and has the same characteristics as an arduino UNO, but in a much smaller format. [10] This element is in charge of controlling the obstacle warnings to the user, and determining with the help of sensors the obstacles and the position of the cane so that the system can determine if the user is at rest or moving, allowing the device to work in a way intelligent activating or deactivating the messages (audio and / or vibration) depending on the user. [11].

\section{Ultrasonic Sensor:}

It is the element that detects the obstacles of objects and cavities, the device uses two, one placed near the handle of the cane responsible for detecting objects and the other placed near the tip responsible for detecting steps, sidewalks and cavities.

\section{Tilt sensor:}

It is in charge of detecting the position of the cane in order to detect if the user is in motion so that the microcontroller activates or deactivates the warnings.[12]

\section{Buzzer:}

It is a small horn that is responsible for giving the user sound warning.

\section{Vibrating Motor:}

It is an engine with an irregular weight on the tip, which when turning, causes a vibration, which makes the stick vibrate giving a silent signal to the user.

\subsection{Interfaces}

\section{Input peripherals:}

Ultrasonic Sensors:Measure the distance to the ground or objects in front of the user.

Cane position (tilt sensor):It is responsible for detecting if the cane is tilted (user in motion) or in an upright position (user at rest).

Selection switch: Allows you to choose between the output peripherals to have audio warning signals, vibration signals or both.

\section{Output peripherals:}

Vibrating Motor: Motor that has a counterweight in the tip, when turning generates a vibration that is transmitted to the stick from the device.
Buzzer: It is a device capable of generating audio that audibly alerts the user.

ON/Off button: It is a button that turns the device on or off, which allows you to turn it off at any time to save energy.

\section{Case}

The case of the device was made with a $3 \mathrm{D}$ printer, being modeled with Sketchup software, which is a 3D modeling software developed by Google. It was printed using an ABS filament, very common in $3 \mathrm{D}$ printing.

\subsection{Device Operation}

The device has 2 ultrasonic sensors, the lower one is connected to a retractable cable in the main module, which is necessary to stretch to place it near the tip of the cane pointing to the ground, while the second one is located near the handle of the cane pointing to the front in search of any object. With the objective that the device be able to detect objects in front of the user; as well as cavities that are in the ground. The upper sensor seeks to detect objects in front of the user at a distance of $1.2 \mathrm{~m}$; whether chairs, tables, walls or people. The lower sensor is responsible for detecting steps, sidewalks or cavities in the ground greater than $10 \mathrm{~cm}$. Giving as a warning sign to the person using the cane an audible signal, a vibrating signal or both at the same time, which can be chosen by means of a 3-position selector.

There is also an inclination sensor that is able to detect when the cane is tilted (indicating that the user is moving) and when it is vertical (indicating that the user is waiting or resting), by detecting that the cane is vertical, the engine and the buzzer are deactivated entering the system in idle mode. Finally, the user can choose between an audible signal, vibratory signal or both through a 3 position switch. The device also has a water puddle detection system; however, the lower sensor cable is retractable and has 4 wires, which the ultrasonic sensor needs to work; and 2 more wires are needed to fully implement water detection; however, no retractable cable was found that had 6 wires, therefore, this feature was only partially implemented.

To power the circuit a power bank was built, which has a charging module, a $5 \mathrm{v}$ voltage booster and a $2000 \mathrm{mAh}$ battery, besides an ON/Off button in order to save energy. See figure 3 .

\section{RESUlTS}

Displacement tests were performed with a person with visual impairment, who indicated that the project is very useful for their day-to-day life, since it allows them to know that an obstacle is in front of them even before they physically touch it with the cane, in addition to the device detecting steps individually so that while they are going down they warn them that another step is coming until the 
warnings cease the person knows that the ladder has ended.

The device has a 2000mA (mili Amperes) rechargeable battery, which can be recharged with a conventional cell phone charger, through a micro-USB port (see figure 5). Having a charging time of approximately 45 minutes (43 minutes in the tests).

The device was under an autonomy test in which a constant detection of a cavity was simulated with both active warning signals (the mode that consumes the most energy); The device was able to offer warning signals continuously for more than 5 hours. Taking into account that the system is at rest when the user moves and that the warnings are only activated when an object or a cavity is detected, the autonomy of the device will increase; and if this is added that the vibration warning or the auditory warning (which consume less) is chosen, it can be concluded that the autonomy is greater than 5 hours. See table 1 power consumption in section IV

These devices have a detection of objects in front of the user and of cavities on the ground, as shown in figure 7 , there is a sensor near the handle of the cane and another near the tip; which allows a simultaneous detection of both obstacles.

During the tests it was noted that the system is not only capable of detecting cavities, but that it is also capable of detecting individual steps, a favorable feature, since it allows the user to be aware of when a ladder ends while it is going down.

\section{Figures AND TABLES}

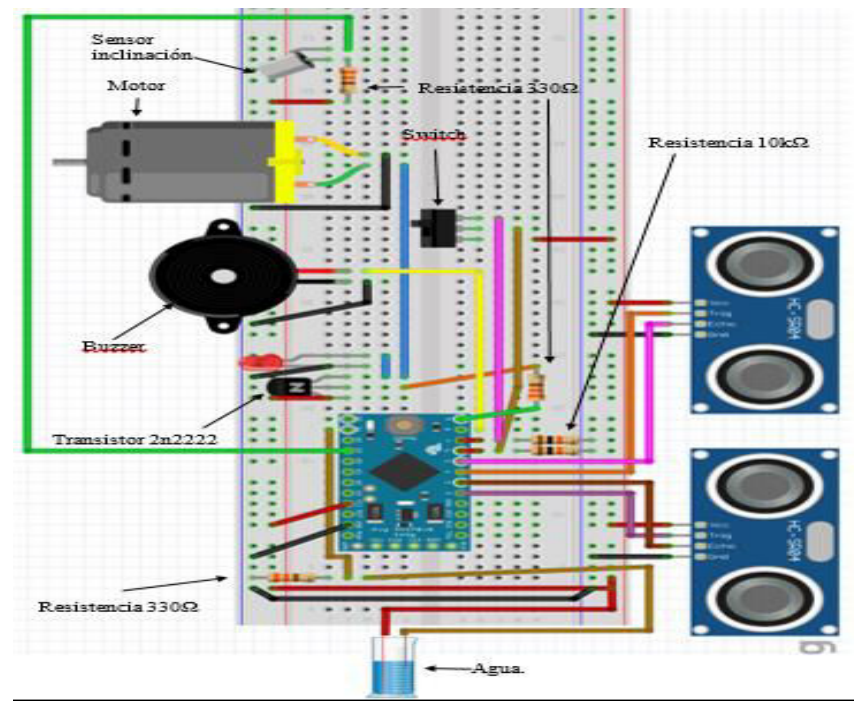

Figure 1. Scheme of de device.

A scheme of de circuitry of the divice developed on the software Fritzing.

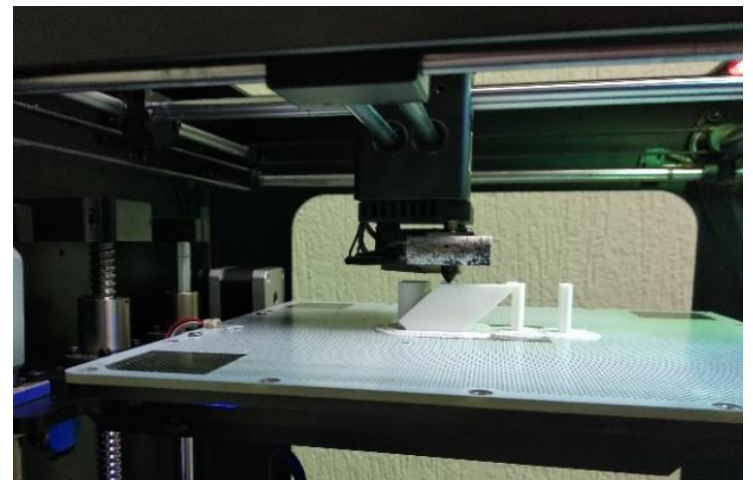

Figure 2. Printing in 3D.

In the figure 2 can be seen how the $3 \mathrm{D}$ printer is creating a part of the case of the device.

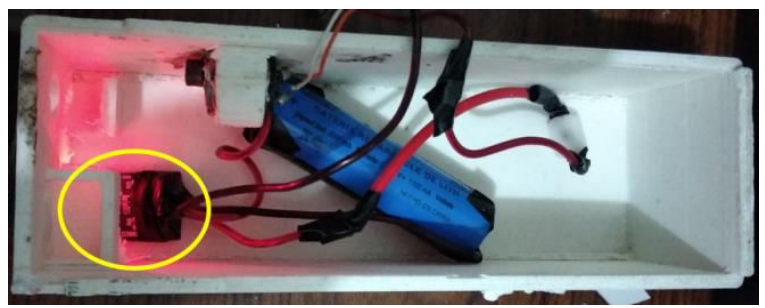

Figure 3. Power bank in the case of the device, Yellow circle is the charging element.

This is the case where is inserted the PCB, in figure 3 it can be seen the power bank assembled with the ON/OFF button.

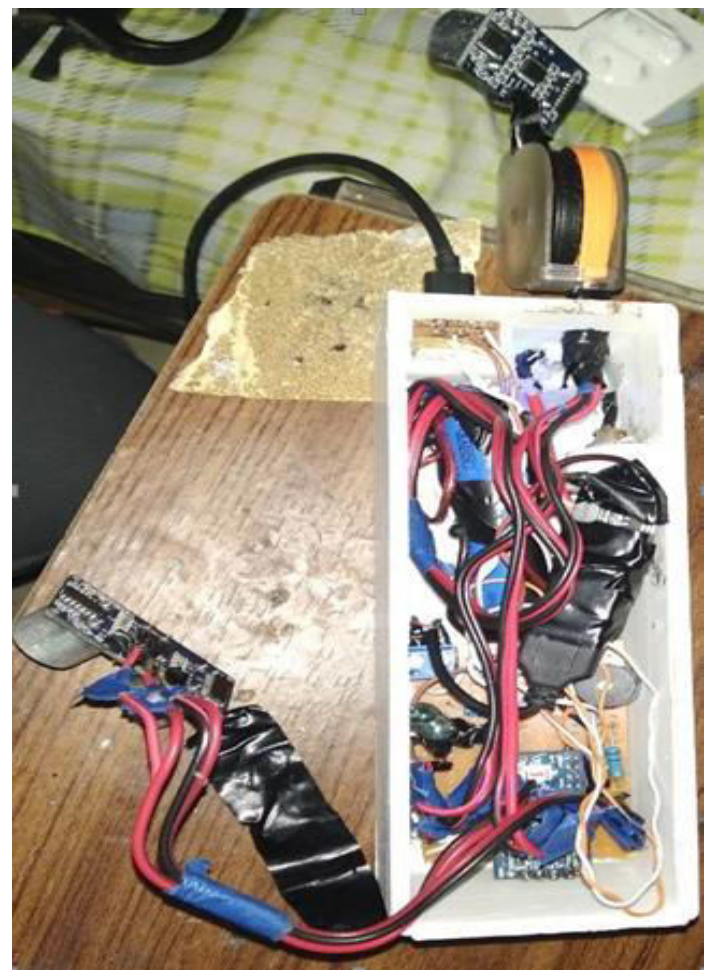

Figure 4. Device Circuitry

In figure 4 is presented the device circuitry with all the components weled to the PCB. 


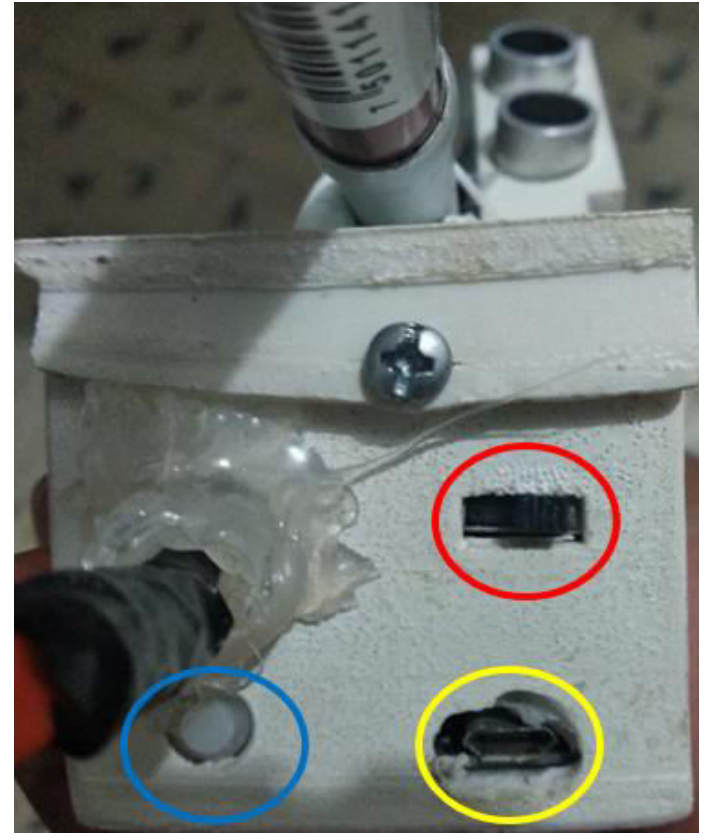

Figure 5. Controls of the device, Yellow circle is charge port, Red circle is the selection switch and blue circle is the on/off button.

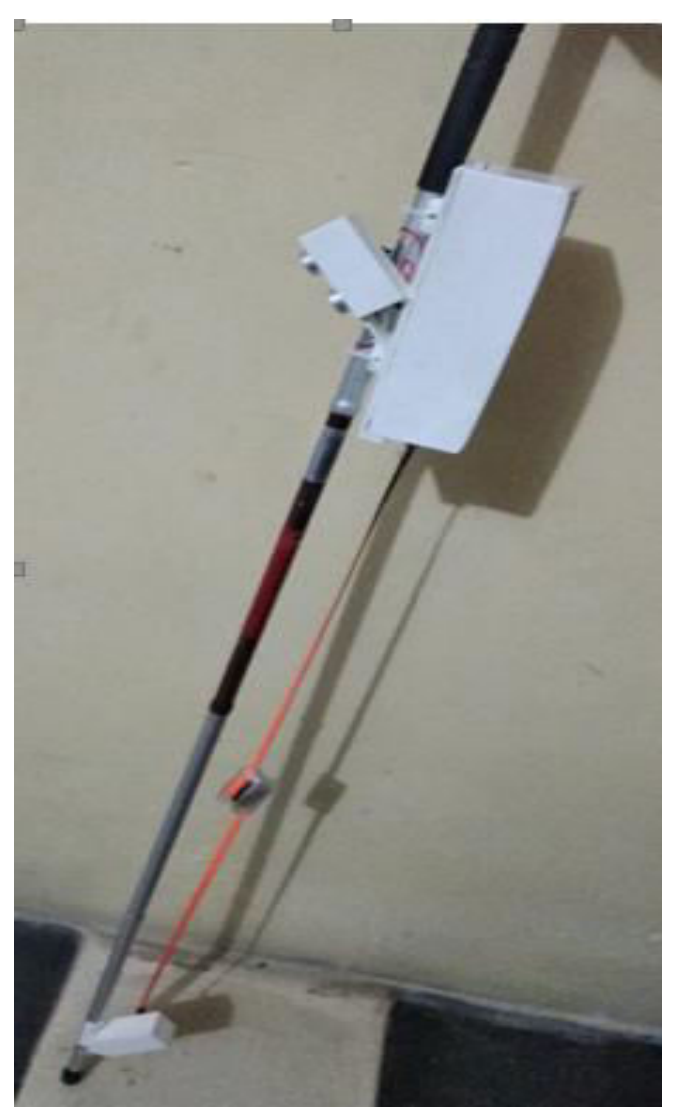

Figure 6. Armed Device

In figure 6 it can be seen the device completely finished and implemented in a White cane.

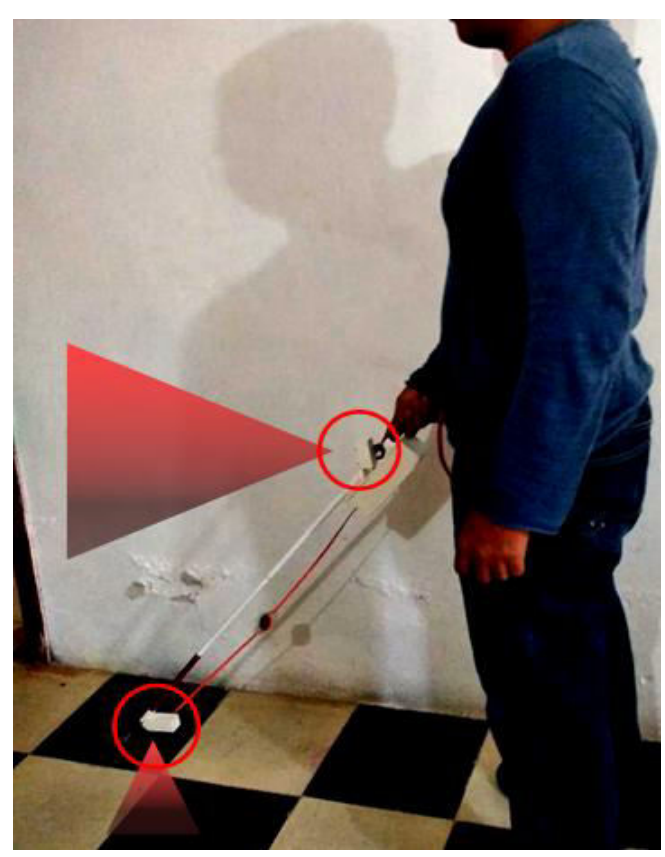

Figure 7. Device functioning. The triangles in red are the area of detection; and the red circles are the ultrasonic sensors.

The device is able to detect both in front and the ground, in order to avoid obstacles that can be dangerous for the user, as it can be seen in figure 7 with the triangles.

\begin{tabular}{|l|l|}
\hline Warning mode & Power consumption \\
\hline Stand-by & $25 \mathrm{~mA}$ \\
\hline Buzzer & $43 \mathrm{~mA}$ \\
\hline Motor & $160 \mathrm{~mA}$ \\
\hline Both & $204 \mathrm{~mA}$ \\
\hline
\end{tabular}

Table 1. Power consumption.

\section{CONCLUSION}

As for what was previously addressed, the device has a relatively accessible ease of use and construction, built with relatively easy-to-find elements, in addition to the fact that it has assistance in an area where few, if not, no other project for people with visual impairment covers, which is the detection of cavities, sidewalks and steps, since most of the tools available to them are concentrated on the objects with which the user can collide, which although it is important to detect them, Detecting the cavities is the same or even more important since if a person capable of seeing can stumble with relative ease, one who has visual impairment, it is very difficult to detect cavities with conventional means. Even when the user has a guide $\operatorname{dog}[13]$, he is still exposed to these accidents, since the dog continues on his way, however, as an example, the dog is not aware if his owner will avoid the hole to his left (in case the dog walks to the right of the person).

With the creation of the device, the need was discovered not only to detect this objects and cavities, but it was improved because it is able to determine approximately how deep is a cavity through the vibration and how close 
an object is through the frequency of signals, offering a detection that goes from Chest level to below feet. So a way to return is provided; even to a certain extent; the autonomy and independence of a person contributing in this way to their self-esteem and therefore to the social, labor, and offering an extra tool to get out of the isolation that many have; offering one more tool to improve the quality of life of people with visual disabilities.

\section{REFERENCES}

[1] ONCE. (December 2013). www.once.es. Obtainded from: Conceptos de ceguer y deficiencia visual: https://www.once.es/dejanos-ayudarte/la-discapacidadvisual/concepto-de-ceguera-y-deficiencia-visual

[2] OMS. (August 2014). www.who.int. Obtainded from: 10 datos acerca de la ceguera y la discapacidad visual:

https://www.who.int/features/factfiles/blindness/blindness _facts/es/index4.html

[3] Utreras, N. L. "Desarrollo de un dispositivo que mida la distancia a un objeto emulando el efecto de un bastón para personas invidentes.", Engeneering degree, Escuela Politécnica Nacional. Quito, Ecuador 2004.

[4] Codina, D. B. (November 2016). Obtainded from: asociaciondoce.com. Obtenido de ULL Media (Universidad de La Laguna): https://asociaciondoce.com/2016/11/15/tecnica-contactoconstante-tecnica-de-los-dos-puntos-tecnica-diagonal-conel-baston-de-movilidad/

[5] Borenstein, J., \& Ulrich , I. (April 1997). Obtainded from: The GuideCane - A Computerized Travel Aid. Obtenido de The University of Michigan: http://www-

personal.umich.edu/ johannb/Papers/Paper65/Paper65.ht $\mathrm{ml}$

[6] New Lease on Sight: Glasses Helping Blind to 'See'. (September 2016). Obtainded from: https://www.orcam.com/en/media/new-lease-on-sightglasses-helping-blind-to-see/

[7] Mysmartcane. (n.d.). Obtainded from: http://mysmartcane.ca: http://mysmartcane.ca

[8] Incluyeme. (June 2015). Incluyeme.com. Obtainded from: Todo lo que necesitas saber sobre Discapacidad Visual: https://www.incluyeme.com/todo-loque-necesitas-saber-sobre-discapacidad-visual

[9] ORCAM. (May 2018). www.orcam.com. Obtainded from: Conoce los colores de los bastones guía para ciegos: https://www.orcam.com/es/blog/conoce-loscolores-de-los-bastones-guia-para-ciegos/

[10] IJANA (October 28, 2018). https://www.ijana.in/ Obtained from: Traffic Control on
Cruise Ships for Autonomous Vehicles Applying Artificial Neural Network: https://www.ijana.in/papers/V10I4-9.pdf

[11] Xataka. (3 de Agosto de 2018). www.xataka.com. Obtainded from: Qué es Arduino, cómo funciona $y$ qué puedes hacer con uno: https://www.xataka.com/basics/que-arduino-comofunciona-que-puedes-hacer-uno

[12] Sensor de inclinación (Tilt Switch). (s.f.). Obtainded from: www.prometec.net: https://www.prometec.net/tilt-switch/

[13] Excelsior.(October 2018). excelsior.com.mx. Obtainded from: Estas son las 3 cosas que debes saber sobre los perros guía: https://www.excelsior.com.mx/nacional/estas-son-las-3cosas-que-debes-saber-sobre-los-perros-guia/1269188

\section{Biographies}

Ayax Israel Isidro Alvarado Master in information technology. His research area is information technology.

Victor Manuel Arias Peregrino. Phd in technology development. His research area is the development of new technologies.

Dulce Maria Leon de la O. Master in system engineering. Her research area is information technology.

Alejandro Hernández Cadena Phd in technology development. His research area is the development of new technologies.

Jose Ángel Jesus Magaña Phd in technology development. His research area is the development of new technologies. 